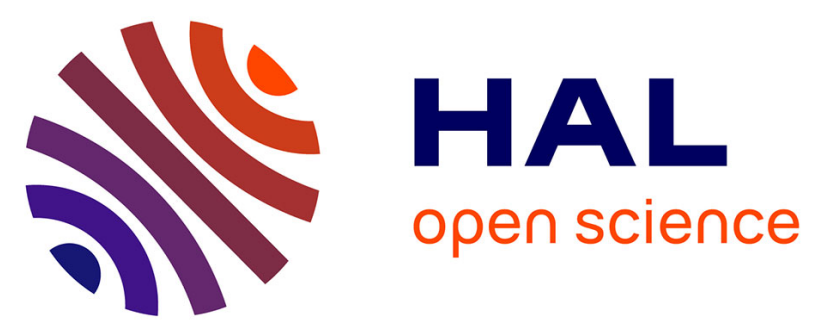

\title{
Incorporating Indigenous Perspectives in Provision of E-government Services: The Case of Tanzania
}

Bakari Mashaka, Neil Mcbride, Kutoma Wakunuma

\section{To cite this version:}

Bakari Mashaka, Neil Mcbride, Kutoma Wakunuma. Incorporating Indigenous Perspectives in Provision of E-government Services: The Case of Tanzania. 15th International Conference on Social Implications of Computers in Developing Countries (ICT4D), May 2019, Dar es Salaam, Tanzania. pp.192-202, 10.1007/978-3-030-19115-3_16. hal-02281291

\section{HAL Id: hal-02281291 \\ https://hal.inria.fr/hal-02281291}

Submitted on 9 Sep 2019

HAL is a multi-disciplinary open access archive for the deposit and dissemination of scientific research documents, whether they are published or not. The documents may come from teaching and research institutions in France or abroad, or from public or private research centers.
L'archive ouverte pluridisciplinaire $\mathbf{H A L}$, est destinée au dépôt et à la diffusion de documents scientifiques de niveau recherche, publiés ou non, émanant des établissements d'enseignement et de recherche français ou étrangers, des laboratoires publics ou privés. 


\title{
Incorporating indigenous perspectives in provision of e- government services: The case of Tanzania
}

\author{
Bakari Mashaka ${ }^{10000-0002-3276-0712]}$, Neil McBride ${ }^{2[0000-0002-7110-0709]}$ and Kutoma \\ Wakunuma ${ }^{3[0000-0002-8236-3221]}$ \\ Centre for Computing and Social Responsibility \\ De Montfort University, Leicester, UK \\ bmwageni@gmail.com, \{nkm, kutoma\}@dmu.ac.uk
}

\begin{abstract}
This paper reports on the gap on perceptions of e-government for indigenous inclusion in Tanzania. E-government provisions in developing countries are linked with the use of ICT4D to support development plans. Literature indicates that development issues, cultural context and consideration of local communities' requirements play a crucial role in facilitating adoption of e-government systems. Use of mobile phones in local communities and sharing mobile device facilities presents a unique phenomenon on utilizing e-government services in Tanzania. Drawing from in-depth interviews from government officials and citizens, the paper argue that perceived gap between central government and local communities is caused by a number of issues. The results indicate that even with few available e-government services, citizens are still keen to use them. It also emerged that there is a gap on computing facilities, central government was found to have all required minimum devices and support to access e-government services and the same was missing to the local communities. Among citizens, mobile phones were preferred way of accessing e-government services as compared to other means since they are convenient and are more personal and hence providing feeling of ownership. For the e-government services to benefits indigenous communities there is a need to address problems associated with the lack of available key e-government services in rural areas, lack of skills among government officials on public administration and development issues as well as underutilization of mobile phone for e-government services.
\end{abstract}

Keywords: Mobile phones, e-government, local communities, ICT4D.

\section{Introduction}

Provision of e-government services in developing countries is regarded as a critical aspects in ICT4D initiatives. To implement e-government projects, information and communication technology (ICT) is used to facilitate innovation and improve public service delivery [1]. However the key e-government services have concentrated on transactional delivery such as payment of central government taxes, local council collections, fines and other forms of government payments. This approach hinders the potentials of reaching many local communities especially those living in rural areas who may not have interactions with these systems [2]. In developing countries, indigenous citizens mainly living in rural areas are more concerned with the provision 
of key social services such as health, education, food and water. However technology infrastructure in most of the rural areas is still a challenge. Technology infrastructure can support provision of basic services such as water supply, health facilities, education and communication [51]. However most of these services can take a while before they are easily available in rural areas [52]. Lack of these services can hinder indigenous citizens mostly living in rural citizens to realize access to basic needs and lead a meaningful life. Malecki [53] and Nandi [54] emphasize the needs to use information and communication technology (ICT) to address these challenges in rural areas. For example Malecki [53] emphasize the need to send people with skills on various technologies including ICT to support rural citizens in learning and acquisition of new technology [53] while Nandi [54] highlight the need to use affordable technologies such as access of ICT facilities for communication in rural communities.

The current practice in developing countries like Tanzania, central government is the one driving e-government projects and monitor the operations [3]. This approach tends to ignore how people are working on their day to day activities and lean more on high level issues. Moreover most of the donors who fund e-government projects prescribe the requirements and thereafter solutions to the targeted developing countries. This create a donor receiver relationship which is referred by Zheng \& Walsham [4, p.238] as "unfavourable inclusion". As a result most of the local communities perceive central government approach as interference and therefore causes a number of e-government initiatives not to work locally [5].

In another context, mobile phones are currently known to provide a unique avenue for digital access by availing various internet and mobile services traditionally accessed through desktop computers and laptops. ITU reports that by 2015, there were 7 billion people connected to various mobile phone services [6] with 5.5 billion people representing $92 \%$ residing in developing countries. The figure can even be extrapolated to $100 \%$ as people in developing countries have a tendency to share mobile phone because of their culture and living style [7]. These statistics also show there is a potential for use of mobile phones services to support various social and economic activities. With more smart phones becoming cheaper, there is also an opportunity of mobile phone usage in many public services such as health, education and social care [6, 8-10] and even expanding participation of citizens in the government affairs [11]. Considering the above key issues, mobile phones have emerged as one of the key tools to engage local communities in provision of e-government services.

\subsection{Tanzania Context and Use of Mobile Phones}

Tanzania is located on the eastern part of Africa with a population of 47 million people with more than $70 \%$ residing in rural areas [12]. Kiswahili is a national language spoken throughout the country. It is still a developing country with most of the citizens de-pending on the agriculture as their main economic activity. Other key sectors of the economy include tourism, mining, finance and construction. Although the real gross domestic product (GDP) is growing at the rate of $7 \%$, most of the citizens are 
still leaving below poverty line [13]. This may be explained in terms of the inequality in the society whereby few citizens in towns enjoy comfortable life as compared to the majority residing in rural areas.

The number of people who own mobile phones in Tanzania has increased considerably. Tanzania Communication Regulatory Authority (TCRA) reported that in 1995 there were only 2 thousand mobile phone subscribers. This number had increased to 8 million in December 2007 and as of December 2015, there were 39 million mobile phone subscribers [14]. Comparing these figures with the country current population of 47 million [12], this is equivalent to 70 mobile subscribers per 100 people with majority of citizens residing in rural areas [12]. This proliferation of mobile phones provides a good avenue for the government to interact with citizens. In fact private sector has utilized this opportunity through varieties of initiatives including mobile money as mentioned above, mobile internet and mobile business. There is therefore a need for governments in developing countries to investigate on how the use of mobile phones and their associated platforms to facilitate understanding of social gaps in provision of e-government services for local communities.

\subsection{Need for a study on e-government on social inclusion}

The above discussion shows that e-government in development countries is linked with the ICT4D. However the literature reveals that most of the studies have been concentrated on the adoption of e-government on various sectors for transactional benefits [1, 15-18]. Others have identified trust technology, trust in government, psychology of citizens and risk factors as barriers to the adoption of e-government among citizens [19-24]. Yet, most of these studies rarely focused on the perception of social gaps between central and local government in adoption e-government services.

In this paper, we consider local communities and indigenous citizens as key factors for the success of e-government service delivery. We question the importance of under-standing the social gap between central government and local communities for successful adoption of e-government systems.

\section{Literature Review}

\subsection{E-government and ICT4D Context}

Early literature has associated e-government with use of computers and automation of key public services functions such as finance and manpower [25]. With the wide spread of internet; e-government was later defined to include provision of online services using the web technology [26-27]. E-government is nowadays considered to be more than online presence through websites and e-mails as it also includes various stakeholders and provides special interest to citizens' involvement and consideration of wider issues, social media and mobile phones [1, 28-29]. However, these defini- 
tions puts emphasize on the use of various information and communication technology (ICT) tools to provide e-government services. As a result they ignore needs to consider various processes within the public offices and citizens before attempting to apply any kind of technology. For example citizens in rural areas may need only to know the prices of agricultural products they grow in the market. In this case, a mobile phone can serve the purpose better than constructing a telecentre. In some cases, a technology may not be needed at all, only a need to reorganise the existing processes in public offices to get the desired result.

Word Bank report shows digital divide is still a world issue with African countries facing "access digital divide" while Europe is facing "capability divide". The report also showed that, in Africa, the gap is double between rural and urban, mature and young as well as those with low income compared to those with higher income [30] . Digital divide is a challenge facing African countries and fails short of solution due to limited technological and economic resources. Example of this is the initiative by the some governments in Africa to rollout one laptop per child across all public schools. Most of these projects did not materialize [31] as they did not consider other components of development such as availability of teaching facilities, teachers training, food for the students and electricity availability in schools [32-33]. This calls to link between social and economic issues when implementing ICT4D in developing countries where the social and cultural context are considered as opposed to the political ambitions. In order to link social and economic issues, the need of indigenous communities should be considered.

The other challenge on ICT4D initiatives is on the maintenance and sustainability. Once the donor fund is finished, these projects are rarely financed by a recipient government or benefited institutions. It is not strange to see a number of abandoned telecentres at the end of the ICT4D project left without any maintenance and thus jeopardizing their fundamental purpose of providing digital access to those in needs [34]. This raises a fundamental question; how can ICT4D fulfil the promise to provide digital benefits to the developing countries? Unless the needs of local communities are ad-dressed, most of these ICT4D initiatives may end up not benefiting the intended local communities and remaining as white elephant projects.

\subsection{Mobile Phones and Local Communities}

In line with current context of e-government in developing countries, mobile phones have attracted attention of most governments in the world. These devices have multiple functions such as short messages (SMS), voice calls and simple calculations. With the spread of smartphones, there are even more added functions on top of those found in simple cell phones. While one can use smartphone for calls and SMS, the device can also be used with almost the same function as a desktop computer by connecting to the internet through Wi-Fi or using mobile network technologies (3G and 4G) [35]. It is possible nowadays to receive and send e-mails while travelling attend office work or purchase and make payment. With the widespread of mobile phone to more than three quarter of the world population [30], mobile phones provides an immerse opportunity for governments to provides services and link with citizens. This is crucial in 
developing countries where only $34 \%$ of the citizens have access to computers or internet access but $91.8 \%$ use mobile phones [36].

The use of mobile phones in providing government services has now become part of e-government [37]. The innovation and fast communication of mobile services is considered to be able to bring enormous benefits to the e-government services [3738]. The ability of mobile devices to be accessed anywhere can allow citizens in remote areas to access government services without a need to travel long distances. For example an SMS can be send to citizens as a reminder to attend school meeting, appointment to see a medical doctor and so on. The mobile phone services can also be used in emergencies situations such as floods, fire [37-38] and in protecting vulnerable groups like people with albinism in Africa. Despite these benefits, there has been few initiative and studies on how mobile phones can be used to enhance government services in developing countries [39].

Use of mobile phone for providing government services has its own obstacles. Acquisition of appropriate mobile device and the mobile charges are among the issues that can hinder wider adoption by local communities in developing countries. At first is the costs of using mobile phones. Gilwald and Stock [40] pointed the cost of mobile airtime top up hindering use of mobile services among women in Africa. There is also a tendency for some government agencies to charge higher fees on the use of SMS based services than the market rate and thus hindering people from using their services [41]. Unless the mobile based government services are provided with the incentive to reduce costs of usage or no payment at all, many local communities may run away from these services and therefore deprive indigenous communities access to these crucial services.

We therefore argue that consideration of local communities and their requirements is a key issue in developing and adopting e-government services in developing countries. The services when developed through local communities' perspectives, can facilitate local communities' participation and address most of the problems they are encountering in their areas.

\section{$3 \quad$ Methodology}

The study borrows tools from grounded theory [42] to conduct preliminary interviews aimed at identifying characteristics of the gap on e-government perception from the government and citizens as users. The study is making the ontological assumption that there is a gap between government agencies and the citizens when it comes to creation and utilization of e-government services in Tanzania. This relativist approach will lead to analysis of perceptions on how the central government on one hand and the local communities on the other side views related to e-government provision. As a result the study follows interpretive paradigm using in-depth interviews in order to understanding whether there is a gap between government and citizens and how the gap can be explained. The choice of interpretive approach as opposed to the posi- 
tivism is based on the fact that analyzing perceptions and generate understanding of the gaps between different groups [43] can lead to the development of framework.

In selecting participants, snow ball sampling technique was used [44 pp. 303]. The researcher used a contact person as a starting point and thereafter he was the one who pointed other people to participate in the interviews [45 pp. 3]. This approach ensured participants are comfortable to participate in the study. The problem with this method is getting a sample of respondents who may have similar [44 pp. 303]. However as this was a preliminary study, it was necessary to start with smaller sample to understand the kind of responses and themes before embarking to full data collection. Also four inter-views, two with citizens in Arusha, a local town where researcher lives and the other two with public officers at the government in institution in Dar EsSalaam. These four preliminary in-depth interviews were used to collect data for this study and generate issues surrounding the research questions. In-depth interviews were used so as explore how people view e-government and mobile government and how we can make meaning by analyzing the perceived gaps [44].

The interviews were recorded in a digital recorder after getting permission from the participants. They were later transcribed using oTranscribe web based application. The transcriptions were later analyzed manually to see the emerging coded by adopting grounded theory coding techniques and document the emerging themes [46] (Saldaña, 2015).

\section{$4 \quad$ Findings and Discussion}

\subsection{Support and availability of e-government facilities}

In this aspect, the interviews demonstrated that most government employees have access to computers with internet access. These staff are also provided with training on the use of computers to support the office work. Respondents from government institutions did not describe other type training related to e-government services such as public administration, customer services and government processes. This is justified by one of the staff when describing training on the use of e-government:

"Our office has a very clear policy on training. When I was employed, I was given a basic training on the use of the existing systems. There after we tend to have training whenever we acquire and install a new system. This has helped us to understand the way can use e-government services and how can get the best from it. We also get support from our suppliers if we face any problem from the systems we are using. There are also a number of manuals available and help from the IT Services directorate on the use of each of the system. So to be frank we have all support to make us use the systems".

Without key skills in public administration and citizen services, there is a potential of e-government to incline more on ICT than the whole spectrum of public administration. There is also a lack of training skills on development issues and this may lead of implementing e-government projects with a focus on ICT rather than development agenda [47-48]. 
Respondents representing citizens said they only get some information concerning e-government services through radios and televisions as they have not been involved in any training or advocacy on the use and adoption of e-government services.

"On training, I did not get it. I think there is more to be done. May be myself but I think many people are not conversant on the use of e-government services. Even citizen are not clearly involved in this. Even this concept of e-government is a new terminology to most of us which needs a discussion and analysis for understanding. In this way people can understand what you are talking about. It needs more advocacy and elaboration before people can understand".

The respondent also showed has never heard availability public access areas for computer and internet. Considering citizens as key stakeholders, the lack of government promotion to this group poses a challenge in managing the gap between government and citizens on e-government adoption.

\subsection{Citizens perceptions on e-government services}

Respondents from citizens said that they would like to access or use e-government services in order to avoid unnecessary physical visits to the government offices, increase transparency in public services and easy access to health services. However they pointed hurdles in attaining these wishes. These include unstable e-government systems, lack of citizens' oriented e-government services and awareness of the available e-government services.

"I think the government is trying to provide these services although is still in a very small scale. They are also provided mainly in town areas. Also most citizens do not have access to the internet and they do not even know how to use these ICT technologies. For example if they could know how to use these services, there could have been no queues in the payment of electrical bills or water utilities. Most people know there is Mpesa but they still go and queue, that is because they not have skills on using these devices. So there is a need for more training on the use of e-government".

There is also a perception that these services are targeting urban areas. Considering most of the citizens in Tanzania are located in rural areas [12], this shows a gap between e-government services with the citizens.

\subsection{Mobile phone use and e-government services}

Citizens and government officers showed that mobile phone is currently used not only for communication but also for accessing financial services. People use mobile phones to make payments for water and electricity bills. Affording life through mobile phone was also another key aspect as cited by one of the respondent.

"Eh it has assisted me a lot. For example myself it has assisted me to learn a lot that is happening in the country, social issues and many other issues. Mobile phone is now a fashion and everyone is looking to own it. In this way it has assisted people to know many things happening on the phone. So I can say I got some 
government services through mobile phone and not computers. For example yesterday I was checking results of form four students through mobile phone and I manage to see my young sister results through mobile phone. Also how to pay and running family, my mobile phone is assisting me a lot".

The same respondent also showed how he has used mobile phone to call someone to login to the internet and check the national examination results for his young sister. Although the respondent did not have access to the computer with internet access, he was able to get the results instantly. This demonstrates how mobile phone can mediate a communication with another person in order to get access to the internet based services. However the respondent was also concerned that government is not using mobile phone for providing services.

"You know let's be realistic. This issue of saying there is information from the government through mobile phones is not widely available. Say you can receive a text message about election but not that large extent. Even if you ask someone about last time has received information through mobile phone very likely they will not remember or know anything. This is different from the way people receive information from the televisions or radios. So in the mobile phone, I have not received any thing tangible from the government rather than getting messages from those who are contesting for the post. So I got many messages from contestants and not the government".

There is still underutilization of mobile based services in providing e-government services. As mobile services can provide quick response to most of the developing countries problems, this creates a gap between the government and the citizens.

\section{$5 \quad$ Discussion and Conclusion}

The above analysis presented results on how gaps exists between central government and citizens. The notable areas of the gaps are in the areas of e-government facilities between central government and local communities. Central government was found to have all required minimum devices and support to access e-government services while the same was missing to the citizens. There was also a challenge in using e-government services as some services are yet to be available online and even those available are scattered across different government departments making harder for the citizen to access. This may have been caused by the lack of involvement of citizens as key stake-holders as pointed by the interviews participants. On the contrary, even on those e-government services currently used by citizens, most respondents showed they have accessed them through mobile phones. Mobile phones were preferred way of accessing e-government services as compared to other means since they are convenient and are more personal and hence providing feeling of ownership. While there is interest from the government to use of mobile phone for delivering services, the rate of adoption is slow and most citizens are not aware on these services.

This study has tried to provide explanation on the gap available in the use of egovernment in Tanzania. The study showed challenges on using e-government for 
citizens and thus creates gap between citizens as users and e-government providers. The results also shows mobile phones provides an important avenue for citizens to access e-government services. However the government is yet to make use proper use of the mobile services. Additionally, the results showed there is currently no linkage between e-government services and development aspects. This can lead to the adoption of e-government services which are not aligned with the life of the people and thus a failure of the initiatives.

The study recommends the need to empower local communities can be empowered to use mobile phones to access key services (health, agriculture, education etc.) from various government agencies. This can be developed through the use of shared mobile phone facilities among local communities as well as providing training on the use of mobile phones to access e-government services for their own benefits.

The major limitation of this study is a sample size. The sample size used for both citizens and government officials was small to claim saturation of the findings [4950]. The sample did not capture the key areas both in the central government and citizens. As pointed above, citizens participants were selected using a contact person and there-fore raises a potential bias in their responses. Likewise, there was also a need to trans-late interview guide into Kiswahili language for the citizens which may also contribute to the loss of meaning. These deficiencies will be used as input for the full study.

The study did not also incorporate the theory. This was done purposely as it was aimed to get a taste of responses in order to apply appropriate theoretical lens. Future research direction will be on the use of theories to define the key issues for research framework and provide explanation for the gaps on e-government perceptions. In undertaking the full study, the researcher also aims to develop separate interview guides for the citizens and government official so as to analyze the gap between them.

\section{References}

1. Savoldelli, A., Codagnone, C., Misuraca, G.: Understanding the e-government paradox: Learning from literature and practice on barriers to adoption. Government Information Quar-terly 31(1), 63-71 (2014)

2. Guha, J., Chakrabarti, B.: Making e-government work: Adopting the network approach Gov-ernment Information Quarterly 31(2), 327-336 (2014)

3. Kettani, D. and Moulin, B.: E-government for good governance in developing countries: Empirical evidence from the eFez project London: Anthem Press (2014)

4. Zheng, Y., Walsham. G.: Inequality of what? Social exclusion in the e-society as capability deprivation Information Technology \& People 21( 3) 222-243 (2008)

5. Foster, C., Heeks, R.: Why efforts to spread novel ICTs often fail. Appropr. Technol. 41, 59-61 (2014).

6. ITU Statistics http://www.itu.int/en/ITU-D/Statistics/Pages/stat/default.aspx, last accessed 2016/5/17.

7. James, J.: Sharing mobile phones in developing countries: Implications for the digital divide. Technol. Forecast. Soc. Change (78) 729-735 (2011) doi:10.1016/j.techfore.2010.11.008 
8. Porter, G., Hampshire, K., Milner, J., Munthali, A., Robson, E., de Lannoy, A., Bango, A., Gunguluza, N., Mashiri, M., Tanle, A., Abane, A.: Mobile Phones and Education in SubSaharan Africa: From Youth Practice to Public Policy. J. Int. Dev. (28), 22-39. (2016)

9. Ramani, S.: The internet and education in the developing world - hopes and reality. Smart Learn. Environ. (2), 1-16 (2015)

10. Zelezny-Green, R.: She called, she Googled, she knew: girls' secondary education, interrupted school attendance, and educational use of mobile phones in Nairobi. Gend. Dev. 22, 63-74 (2014)

11. Geldof, M., Grimshaw, D.J., Kleine, D., Unwin, T.: What are the key lessons of ICT4D partnerships for poverty reduction? Syst. Rev. Rep. Prep. UNESCO Dep. Int. Dev (2011).

12. National Bureau of Statistics Statistics for Development http://www.nbs.go.tz/ Last accessed 2016/6/3

13. World Bank Group Tanzania Overview http://www.worldbank.org/en/country/tanza-nia/ overview last accessed 2016/24/6

14. TCRA Tanzania Tanzania Quarterly Communications Statistics http://www.tcra.go.tz/images/documents/telecommunication/CommStatsDec15.pdf last accessed 2016/4/24

15. Alomari, M., Woods, P., Sandhu, and K.: Predictors for e-government adoption in Jordan: Deployment of an empirical evaluation based on a citizen-centric approach Inf. Technol. People (25) 207-234 (2012)

16. Bwalya, K.J., Mutula, S.: A conceptual framework for e-government development in resource-constrained countries: The case of Zambia. Information Development. (32)4 11831198 (2016)

17. Kamal, M.M., Hackney, R., Sarwar, K.: Investigating Factors Inhibiting e-Government Adoption in Developing Countries: The Context of Pakistan. Journal of Global. Information Management (21)4 77-102 (2013)

18. Yonazi, J.: Exploring Facilitators and Challenges Facing ICT4D in Tanzania Journal of eGovernment Studies and Best Practices (2012) 1-16. doi:10.5171/2012.703053

19. Khasawneh , T., Abu-Shanab, E.: E-Government and Social Media Sites: The Role and Impact. World Journal of Computer Application and Technology (1)1 10 - 17 (2013)

20. Wang, H., Lo, J,: Determinants of citizens' intent to use government websites in Taiwan” Information Development (29)2 123-137.

21. Abu-Shanab, Al-Azzam, E. Trust Dimensions and adoption of e-government in Jordan International Journal of Information Communication Technologies and Human Development (4)1 39-51 (2012)

22. Rehman, M., Kamal, M., Esichaikul, V.: Determinant of trust in e-government adoption: a case study of Pakistan in AMCIS 2012 Proceedings, pp 1-10 AISeL, Washington (2012)

23. Bannister, F., Connolly, R. Trust and transformational government, a proposed framework for research Government Information Quarterly (28) 2, 137-147 (2011)

24. Alzahrani, L., Al-Karaghouli, W., Weerakkody, V.: Investigating the impact of citizens' trust towards the successful adoption of e-government: a multigroup analysis of gender, age and internet experience Information Systems Management (35) 2 124-146 (2018)

25. Danziger, J., Andersen, K.: The impacts of information technology on public administration: an analysis of empirical research from the "golden age" of transformation International Jour-nal of Public Administration (25)5 591-627 (2002)

26. OECD The e-Government Imperative. Organisation for Economic Co-operation and Devel-opment OECD, Paris (2003)

27. Seifert, J.: A primer on e-government: Sectors, stages, opportunities, and challenges of online governance Library of Congress, Washington D.C. (2003) 
28. Guida, J., Crow, M.: E-government and e-governance in ICT4D Information Communication Technology Development Unwin, T.: eds 283-320 Cambridge University Press, Cambridge

29. Heeks, R.: Understanding and measuring eGovernment: international benchmarking studies, in UNDESA workshop,"E-Participation and E-Government: Understanding the Present and Creating the Future” 27-28 UNDESA, Budapest (2006)

30. World Bank World Development Report 2016: Digital Dividends World Bank. Group, Washington D.C. (2016)

31. Villanueva-Mansilla, E.: One Laptop per Child (OLPC) Strategy, in: The International Encyclopedia of Digital Communication and Society John Wiley \& Sons, Inc (2015)

32. Cristia, J., Ibarrarán, P., Cueto, S., Santiago, A., Severín, E.: Technology and child development: Evidence from the one laptop per child program IDB (2012)

33. Hatakka, M., Andersson, A., Grönlund, A: Students' use of one to one laptops: a capability approach analysis Information Technology \& People (26)1 94-112 (2013)

34. TCRA Report on Tanzania Telecentres http://www.tcra.go.tz/images/headlines/telecentresReport_1.pdf last accessed 2016/23/5

35. Feijóo, C.: Next generation mobile networks and technologies: Impact on mobile media in Routledge Companion Mobile Media Goggin, G. and Hjorth, L. 81-93 Routledge, New York (2014)

36. ITU ICT Facts and Figures-The world in 2015 http://www.itu.int/en/ITU-D/Statistics/ Pages/facts/default.aspx last accessed 2016/16/5

37. Amailef, K., Lu, J.: A mobile-based emergency response system for intelligent m-government services. Journal of Enterprise Information Management (24)4 338-359. (2011)

38. Hung, S.., Chang, C.., Kuo, S.: User acceptance of mobile e-government services: An empirical study Government Information Quarterly (30)1 33-44 (2013)

39. Wang, C.: Antecedents and consequences of perceived value in Mobile Government contin-uance use: An empirical research in China. Computer in Human Behavior (34) 140147 (2014)

40. Gillwald, A., Milek, A., Stork, C.: Gender Assessment of ICT access and usage in Africa. Evid.-Based ICT Policy Regulation (1) 5 ResearchICTAfrica (2010)

41. Susanto, T., Goodwin, R.: User acceptance of SMS-based e-government services: Differences between adopters and non-adopters. Government Information Quarterly (30)4 486497 (2013)

42. Charmaz, K.: Constructing grounded theory 2nd ed. Sage, London

43. Bryman, A., Bell, E.: Business research methods, 3rd ed. Oxford University Press, Oxford (2011)

44. Saunders, M., Lewis, P., Thornhill, A: Research methods for business students 7th ed. Pear-son Education, London (2016)

45. Swanson, L.: A generational divide within the class-based production of girls in American youth soccer. Soccer \& Society (17)6 898-909 (2015)

46. Saldaña, J.: The coding manual for qualitative researchers 3rd ed. Sage, London (2016)

47. Heeks, R.: ICT4D 2016: New priorities for ICT4D policy, practice and WSIS in a post2015 World IDPM Development Informatics Working Paper no. 59 (2016)

48. Walsham, G.: Development informatics in a changing world: Reflections from ICTD2010/2012 Information Technology International Development. (27)2 49-54 (2013)

49. Fusch, P., Ness, L.: Are we there yet? Data saturation in qualitative research. Qualitative Report (20)9 1408-1416 (2015)

50. Lichtman, M.: Qualitative research for the social sciences SAGE Publications, Thousand Oaks, CA (2013) 
51. Developing rural infrastructure http://www.ilo.org/asia/WCMS_099466/lang--en/index.htm accessed 2016/04/2

52. Heimerl, K., Menon, A., Hasan, S: Analysis of Smartphone Adoption and Usage in a Rural Community Cellular Network, in ICTD 2015 May 15 - 18, 2015, Singapore (2015)

53. Malecki, E: Digital development in rural areas: potentials and pitfalls Journal of Rural Studies 19 201-214 (2003)

54. Nandi, S., Thota, S., Nag, A., Divyasukhananda, S., Goswam, P., Aravindakshan, A., Rodriguez, R., Mukherjee, B : Computing for Rural Empowerment: Enabled by Last-Mile Telecommunications IEEE Communications Magazine (54)6 102-109 (2016) 